\title{
HUBUNGAN SANITASI DASAR DENGAN KEJADIAN DIARE PADA BALITA DI DESA TANJUNG BARU WILAYAH KERJA UPTD PUSKESMAS TANJUNG BARU TAHUN 2019
}

\author{
Eva Yustati,SKM.,M.K.M \\ Dosen S 1 Kesehatan Masyarakat STIKES Al-Ma'arif Baturaja \\ Email : eva_yustati@yahoo.com
}

\begin{abstract}
ABSTRAK
Latar belakang : Kasus kejadian diare pada balita di Wilayah kerja UPTD puskesmas tanjung baru tahun 2017 terdapat 705 balita dengan diare sebanyak $35(4,00 \%)$ tahun 2018 terjadi peningkatan yaitu terdapat 864 balita dengan diare 41 (4,74\%). Tujuan Penelitian yaitu untuk mengetahui hubungan sanitasi dasar dengan kejadian diare pada balita di desa tanjung baru wilayah kerja UPTD puskesmas tanjung baru tahun 2019. Metode penelitian : jenis penelitian menggunakan pendekatan cross sectional, pengumpulan data dilakukan dengan cara observasi dan wawancara langsung dengan menggunakan kuesioner dan checklist. Sampel dalam penelitian ini yaitu berdasarkan hasil perhitungan besar sampel sebanyak 180 sampel. Hasil penelitian : Hasil penelitian diperoleh 37,8\% responden yang menderita diare, Responden 48,3\% ketersediaan sarana air bersih tidak memenuhi syarat kesehatan, 40,0\% ketersediaan jamban tidak memenuhi syarat kesehatan, 42,2\% ketersediaan SPAL tidak memenuhi syarat kesehatan.

Kesimpulan :Dari hasil penelitian menunjukan bahwa proporsi responden yang ketersediaan air bersih mememenuhi syarat yang balitanya mengalami kejadian diare lebih kecil sebanyak 5,4 \% dibandingkan dengan responden yang ketersediaan air bersih tidak mememenuhi syarat kesehatan yang balitanya mengalami kejadian diare sebanyak $72,4 \%$. setelah dilakukan Uji statistik Chi-square didapat $\mathrm{p}$ value 0,000 maka hasil tersebut menunjukan adanya hubungan yang bermakna antara ketersediaan air bersih dengan kejadian diare. kejadian diare sebanyak 13,0\% lebih kecil dibandingkan dengan responden yang ketersediaan jamban tidak tersedia mengalami kejadian diare sebanyak $75,0 \%$, setelah dilakukan Uji statistik Chi-square didapat $\mathrm{p}$ value 0,000 maka hasil tersebut menunjukan ada hubungan yang bermakna antara ketersediaan jamban dengan kejadian diare.ada hubungan yang bermakna antara ketersediaan air bersih dengan kejadian diarepada balita dengan $p$ value 0,000 , ada hubungan bermakna antara ketersediaan jamban dengan kejadian diare pada balita dengan $p$ value 0,000 , ada hubungan yang bermakna antara ketersediaan SPAL dengan kejadian diare pada balita dengan $p$ value 0,000 .
\end{abstract}

Kata kunci : ketersediaan Air bersih, ketersediaan jamban, ketersediaan SPAL dan kejadian Diare

\section{ABSTRACT}

Background: Cases of diarrhea in infants in the working area of the UPTD of the new tanjung puskesmas in 2017 there were 705 infants with diarrhea as many as 35 (4.00\%) in 2018 there was an increase namely there were 864 children with 41 diarrhea (4.74\%). The purpose of this study was to determine the relationship of basic sanitation with the 
incidence of diarrhea in infants in tanjung baru village, the working area of the new Tanjung Puskesmas UPTD 2019. Research methods: this type of research uses a cross sectional approach, data collection is done by observation and direct interviews using a questionnaire and checklist. The sample in this study is based on the results of the calculation of the sample size of 180 samples. The results of the study: The results obtained $37.8 \%$ of respondents suffering from diarrhea, Respondents $48.3 \%$ availability of clean water facilities did not meet health requirements, $40.0 \%$ availability of latrines did not meet health requirements, $42.2 \%$ availability of SPAL did not meet health requirements. Conclusion: The results of the study showed that the proportion of respondents whose availability of clean water fulfilled the requirements of toddlers experiencing diarrhea events was smaller by $5.4 \%$ compared to respondents whose availability of clean water did not meet health requirements whose toddlers experienced diarrhea as much as $72.4 \%$. After Chi-square statistical tests obtained p value 0,000, these results indicate a significant relationship between the availability of clean water and the incidence of diarrhea. the incidence of diarrhea was $13.0 \%$ smaller than that of respondents whose availability of latrines was not available. The incidence of diarrhea was $75.0 \%$, after a Chi-square statistical test obtained p value of 0,000, the results showed a significant relationship between availability of latrines and the incidence diarrhea. There is a significant relationship between the availability of clean water and the incidence of diarrhea in infants with a $p$ value of 0,000, there is a significant relationship between the availability of latrines with the incidence of diarrhea in infants with a $p$ value of 0,000, there is a significant relationship between the availability of SPAL with the incidence of diarrhea in infants with a p value 0,000.

Keywords: availability of clean water, availability of latrines, availability of SPAL and the incidence of diarrhea

\section{PENDAHULUAN}

Penyakit diare hingga saat ini masih menjadi masalah di Indonesia. Padahal berbagai upaya penanganan, baik secara medik maupun upaya perubahan tingkah laku dengan melakukan pendidikan kesehatan terus dilakukan. Namun, upaya-upaya tersebut belum memberikan hasil yang menggembirakan. Setiap tahun penyakit ini masih menduduki peringkat atas, khususnya di daerah-daerah miskin (Kurniawan, 2014).

Diare adalah buang air besar (BAB) dengan konsistensi faeces lebih cair dengan frekuensi >3 kali sehari,
Kecuali pada neonatus (bayi $<1$ bulan) yang mendapatkan ASI biasanya buang air besar dengan frekuensi lebih sering (5-6 kali sehari) dengan konsistensi baik dianggap normal (Kemenkes, 2018)

Menurut data World Health Organization (WHO), diare masih jadi penyebab nomor satu kematian balita di seluruh dunia. Di Indonesia, diare adalah pembunuh balita nomor dua setelah ISPA (Infeksi Saluran Pernapasan Akut). Sementara UNICEF (Badan Perserikatan Bangsa-Bangsa untuk urusan anak) memperkirakan bahwa, setiap 30 detik ada satu anak yang meninggal dunia 
karena diare. Di Indonesia, setiap tahun 100.000 balita meninggal karena diare (United States Agency for International Development, 2015).

Menurut hasil Riset Kesehatan Dasar 2018, jumlah kejadian diare di Indonesia sebanyak 6,8\%, tertinggi berada di Provinsi Bengkulu sebanyak 8.9\% dan Terendah di Provinsi Bangka Belitung 3,2\%.(Kemenkes RI, 2018).

Berdasarkan dari data Dinas kesehatan provinsi Sumatera Selatan angka kejadian diare tahun 2017 jumlah kasus diare sebanyak $227,780 \quad(2,86 \%) \quad$ kasus (Dinkes Sumsel, 2017).

UPTD Puskesmas Tanjung Baru merupakan salah satu dari 18 UPTD Puskesmas di Kabupaten OKU yang berada di Kecamatan Baturaja Timur, penelitian dilaksanakan di puskesmas tanjung baru dikarenakan puskesmas tanjung baru belum ada peneliti yang melakukan penelitian diare pada balita di puskesmas tanjung baru di karenakan puskesmas tersebut baru berjalan 3 tahun dari tahun 2016.

Dampak penyakit yang paling sering terjadi akibat buang air besar sembarangan ke sungai adalah diare.

Berdasarkan data diatas penulis tertarik untuk meneliti "Hubungan sanitasi dasar dengan kejadian Diare pada Balita di Desa Tanjung Baru Wilayah
Kerja UPTD Puskesmas Tanjung Baru Tahun 2019

\section{METODE PENELITIAN}

Jenis penelitian yang digunakan adalah survey analitik dengan pendekatan Cross Sectional yang bertujuan untuk menganalisa faktor-faktor yang berhubungan dengan Kejadian diare.

Survei cross sectional yaitu menguji variabel independen (air bersih, jamban dan Ketersediaan saluran pembuangan air limbah) dengan variabel dependen (kejadian diare) dimana data yang didapatkan sekaligus pada saat bersamaan (Notoatmodjo, 2010).

Populasi adalah keseluruhan unit analisis yang karekteristiknya akan diteliti (Sabri, 2008). Populasi dalam penelitian ini adalah seluruh keluarga yang berada di Desa Tanjung Baru Wilayah Kerja UPTD Puskesmas Tanjung Baru pada tahun 2018

Sampel adalah sebagaian atau wakil populasi yang diteliti (Arikunto, 2010), dalam penentuan sampel menggunakan tehnik Random Sampling, dalam penentuan sampel menggunakan rumus dari (Iwan Ariawan, 1998) dalam Notoatmodjo (2010). sebanyak 180 balita. 


\section{HASIL PENELITIAN}

Analisa ini dilakukan untuk mengetahui hubungan antara variabel independen (ketersediaan air bersih, ketersediaan jamban dan ketersediaan saluran pembuangan air limbah) dengan variabel dependen (kejadian diare).

\section{Ketersediaan Air Bersih}

Untuk mengetahui hubungan ketersediaan air bersih dengan kejadian diare dilakukan uji Chi Square

Tabel 5.5

hubungan ketersediaan air bersih dengan kejadian diare pada balita di desa tanjung baru wilayah kerja uptd puskesmas tanjung baru tahun 2019

\begin{tabular}{|c|c|c|c|c|c|c|c|c|}
\hline \multirow{3}{*}{ No } & \multirow{3}{*}{$\begin{array}{c}\text { Ketersediaan } \\
\text { Sarana Air } \\
\text { Bersih }\end{array}$} & \multicolumn{4}{|c|}{ Kejadian Diare } & \multirow{2}{*}{\multicolumn{2}{|c|}{ Jumlah }} & \multirow[b]{2}{*}{$p$ value } \\
\hline & & \multicolumn{2}{|c|}{ Ya } & \multicolumn{2}{|c|}{ Tidak } & & & \\
\hline & & f & $\%$ & $\mathbf{f}$ & $\%$ & f & $\%$ & \multirow{4}{*}{0,000} \\
\hline 1 & tidak tersedia & 63 & 72,4 & 24 & 27,6 & 87 & 100 & \\
\hline 2 & tersedia & 5 & 5,4 & 88 & 94,6 & 93 & 100 & \\
\hline & Jumlah & 68 & 37,8 & 112 & 62,2 & 180 & 100 & \\
\hline
\end{tabular}

Dari tabel 5.5 menunjukan bahwa dilakukan Uji statistik Chi-square didapat proporsi responden yang ketersediaan air $p$ value 0,000 maka hasil tersebut bersih mememenuhi syarat yang menunjukan adanya hubungan yang balitanya mengalami kejadian diare lebih bermakna antara ketersediaan air bersih kecil sebanyak $5,4 \%$ dibandingkan dengan responden yang ketersedian air bersih tidak mememenuhi syarat kesehatan yang balitanya mengalami kejadian diare sebanyak $72,4 \%$. setelah dengan kejadian diare.

\section{Ketersediaan Jamban}

Untuk mengetahui hubungan ketersediaan jamban dengan kejadian diare dilakukan uji Chi Square

Tabel 5.6

hubungan ketersediaan jamban dengan kejadian diare pada balita di desa tanjung baru wilayah kerja uptd puskesmas tanjung baru tahun 2019

\begin{tabular}{|c|c|c|c|c|c|c|c|c|}
\hline \multirow{3}{*}{ No } & \multirow{3}{*}{$\begin{array}{c}\text { Ketersediaan } \\
\text { Jamban }\end{array}$} & \multicolumn{4}{|c|}{ Kejadian Diare } & \multirow{2}{*}{\multicolumn{2}{|c|}{ Jumlah }} & \multirow[b]{2}{*}{ p value } \\
\hline & & \multicolumn{2}{|c|}{$\mathbf{Y a}$} & \multicolumn{2}{|c|}{ Tidak } & & & \\
\hline & & $\mathbf{f}$ & $\%$ & $\mathbf{f}$ & $\%$ & $\mathbf{f}$ & $\%$ & \multirow{4}{*}{0,000} \\
\hline 1 & tidak tersedia & 54 & 75 & 18 & 25 & 72 & 100 & \\
\hline 2 & tersedia & 14 & 13 & 94 & 87 & 108 & 100 & \\
\hline & Jumlah & 68 & 37,8 & 112 & 62,2 & 180 & 100 & \\
\hline
\end{tabular}


Dari tabel 5.6 menunjukan bahwa proporsi responden yang ketersediaan jamban mememenuhi syarat kesehatan mengalami kejadian diare sebanyak 13,0\% lebih kecil dibandingkan dengan responden yang ketersediaan jamban tidak mememenuhi syarat kesehatan mengalami kejadian diare sebanyak 75,0\%, setelah dilakukan Uji statistik Chi- square didapat $p$ value 0,000 maka hasil tersebut menunjukan ada hubungan yang bermakna antara ketersediaan jamban dengan kejadian diare.

\section{Ketersediaan SPAL}

Untuk mengetahui hubungan ketersediaan SPAL dengan kejadian diare dilakukan uji Chi Square

Tabel 5.7

Hubungan ketersediaan SPAL dengan kejadian diare pada balita di desa tanjung baru wilayah kerja uptd puskesmas tanjung baru tahun 2019

\begin{tabular}{|c|c|c|c|c|c|c|c|c|}
\hline \multirow{3}{*}{ No } & \multirow{3}{*}{ Ketersediaan SPAL } & \multicolumn{4}{|c|}{ Kejadian Diare } & \multirow{2}{*}{\multicolumn{2}{|c|}{ Jumlah }} & \multirow{2}{*}{ p value } \\
\hline & & \multicolumn{2}{|c|}{$\mathbf{Y a}$} & \multicolumn{2}{|c|}{ Tidak } & & & \\
\hline & & $\mathbf{f}$ & $\%$ & $\mathbf{f}$ & $\%$ & $\mathbf{f}$ & $\%$ & \multirow{4}{*}{0,000} \\
\hline 1 & Tidak tersedia & 55 & 72,4 & 21 & 27,6 & 76 & 100 & \\
\hline 2 & Tersedia & 13 & 12,5 & 91 & 87,5 & 104 & 100 & \\
\hline & Jumlah & 68 & 37,8 & 112 & 62,2 & 180 & 100 & \\
\hline
\end{tabular}

Dari tabel 5.7 menunjukan bahwa proporsi responden yang ketersediaan SPAL mememenuhi syarat kesehatan mengalami kejadian diare lebih kecil sebanyak $12,5 \%$ dibandingkan dengan responden yang ketersediaan SPAL tidak mememenuhi syarat kesehatan yang mengalami kejadian diare sebanyak $72,4 \%$, setelah dilakukan Uji statistik Chi-square didapat $p$ value 0,000 maka hasil tersebut menunjukan ada hubungan yang bermakna antara Ketersediaan SPAL dengan kejadian diare

\section{PEMBAHASAN}

\section{Ketersediaan Air Bersih}

Dari hasil penelitian menunjukan bahwa proporsi responden yang ketersediaan air bersih mememenuhi syarat yang balitanya mengalami kejadian diare lebih kecil sebanyak 5,4 \% dibandingkan dengan responden yang ketersediaan air bersih tidak mememenuhi syarat kesehatan yang balitanya mengalami kejadian diare sebanyak $72,4 \%$. setelah dilakukan Uji statistik Chi-square didapat $p$ value 0,000 maka hasil tersebut menunjukan adanya hubungan yang bermakna antara 
ketersediaan air bersih dengan kejadian diare.

Hasil ini sesuai dengan penelitian yang dilakukan oleh Candra dkk (2013) Dimana didapatkan hubungan antara ketersediaan air bersih dengan kejadian diare dengan $\mathrm{p}$ Value $=0,00$

\section{Ketersediaan jamban}

Dari hasil penelitian menunjukan bahwa proporsi responden yang ketersediaan jamban mememenuhi syarat kesehatan mengalami kejadian diare sebanyak 13,0\% lebih kecil dibandingkan dengan responden yang ketersediaan jamban tidak tersedia mengalami kejadian diare sebanyak 75,0\%, setelah dilakukan Uji statistik Chi-square didapat $p$ value 0,000 maka hasil tersebut menunjukan ada hubungan yang bermakna antara ketersediaan jamban dengan kejadian diare.

Hasil ini sesuai dengan penelitian yang dilakukan oleh Rahmawati dkk (2012) Dimana didapatkan hubungan antara ketersediaan jamban dengan kejadian diare dengan $p$ Value $=0,00$

\section{Ketersediaan SPAL}

Dari hasil penelitian menunjukan bahwa proporsi responden yang ketersedian SPAL mememenuhi syarat kesehatan mengalami kejadian diare lebih kecil sebanyak $12,5 \%$ dibandingkan denganresponden yang ketersedian SPAL tidak mememenuhi syarat kesehatanyang mengalami kejadian diare sebanyak $72,4 \%$, setelah dilakukan Uji statistik Chi-square didapat $p$ value 0,000 maka hasil tersebut menunjukan ada hubungan yang bermakna antara Ketersedian SPAL dengan kejadian diare.

Hasil ini sesuai dengan penelitian yang dilakukan oleh Kamilla dkk (2012) yang menyatakan ada hubungan antara kepemilikan SPAL dengan kejadian diare pada balita dengan hasil $\mathrm{OR}=0,094$; dengan nilai $p$ Value $=0,001$

\section{KESIMPULAN}

Berdasarkan penelitian yang dilakukan terhadap 180 responden yang merupakan Balita di Desa Tanjung Baru Wilayah Kerja UPTD Puskesmas Tanjung Baru Tahun 2019, maka dapat ditarik kesimpulan sebagai berikut

1. Ada hubungan yang bermakna antara ketersediaan air bersih dengan kejadian diare di Desa Tanjung Baru Wilayah Kerja UPTD Puskesmas Tanjung Baru dimana $p$ value 0,000 .

2. Ada hubungan yang bermakna antara ketersedian jamban dengan kejadian diare di Desa Tanjung Baru Wilayah Kerja UPTD Puskesmas Tanjung Baru dimana $p$ value 0,000 . 
3. Ada hubungan yang bermakna antara ketersedian SPAL dengan kejadian diare di Desa Tanjung Baru Wilayah Kerja UPTD Puskesmas Tanjung Baru dimana $p$ value 0,000 .

\section{DAFTAR PUSTAKA}

1. Arikunto, S. 2010 . Prosedurpenelitian : Suatu Pendekatan Praktik. (EdisiRevisi). Jakarta : Rineka Cipta

2. Chandra, Dr.Budiman. 2007. Pengantar Kesehatan Lingkungan. Jakarta: Penerbit Buku Kedokteran

3. Candra dkk, 2013. Hubungan Antara Keadaan Sanitasi Sarana Air Bersih Dengan Kejadian Diare Pada Balita Didesa Den Bantas Tabanan Tahun 2013. Jurnal Kesehatan Lingkungan Vol. 4 no 1, Mei 2014 : 112-117

4. Darsana, 2012.Faktor-Faktor Yang BerhubunganDenganKepemilikanJa mbanKeluarga Did EsaJehamKecamatanTembukuKabup atenBenglijurnaldiakses 22/04/2016

5. Dinkes Sum-Sel. 2015. Profil Kesehatan Provinsi Sumatera Selatan. Palembang

6. Dinas Kesehatan OKU, 2018. Laporan tahunan jambansehat. Martapura
7. DinkesJabar, 2011. Saatnyamemilih Yang LebihBaikbukan

_HanyaSekedarMembangun'

Jambahhttp : // www. diskes. jabarprov. go.id/ application /modules/ pages/files/STBM2.pdf.

8. Kamila L, Suhartono, Nur Endah, 2012. Hubungan Praktek Personal Hygiene Ibu dan Kondisi Sanitasi Lingkungan Rumah Dengan Kejadian Diare Pada Balita di Puskesmas Kampung Dalam Kecamatan Pontianak Timur. Jurnal Kesehatan Lingkungan Indonesia Vol 11 No 2 / Oktober 2012

9. Kesmas,2014.PengertiandanStandarJ ambanSehat.www.indonesianpublichealth.com/syarat-jambankeluarga/ (04/05/2016)

10. Kemenkes RI, 2018. Profil Kesehatan Indonesia. Jakarta, Kemenkes

11. Notoatmodjo, S.2010. Metodologi Penelitian Kesehatan Edisi Revisi. Rineka Cipta, Jakarta

12. Ningrum, dkk, 2015. AnalisisFaktor yang

BerhubungandenganPemanfaatanJa mban di Kawasan Perkebunan KopieJurnalPustakaKesehatan, vol. 3 (no. 1) Januari 2015 (25/04/2016)

13. Sabri, 2008, Statistik Kesehatan, Rajawali Pers. Jakarta 
14. Soleh, Muhammad, 2002. BeberapaFactor yang berhubungandenganpemanfaatanjam bankeluargaproyek APBD KabupatenJeparaTahun 2001.

15. Soeparman, 2002.PembuanganTinjadanLimbahC air.PenerbitBukuKedokteran EGC. Jakarta.

16. Suharman, dkk, 2010.Tingkat PartisipasiMasyarakatDalamPengad aanJambanKeluargaMelaluiCommun ity Lead Total Sanitation.BeritaKedokteranMasyara kat Vol. 26, No. 3, September 2010 (26/04/2016)

17. Stikes Al-Ma'arif, 2019. Buku panduan penyusunan Skripsi. Baturaja

18. WHO, 2010.People Defecate In The Area Open. Treatment,Prevention and Control.WHO : Geneva.

19. Widiyani, 2013. 42 JutaMasyarakat Indonesia BAB Sembarangan. [internet]. 2013. [2013 December 26] Available from: http://health. kompas. com $/ \mathrm{read} / 2013 / 10 / 18 /$ 1829459/42.Juta.Masyarakat.Indones ia.BAB.Sembarangan 